\title{
Asthma and Atopy in Rural Children: Is Farming Protective?
}

\author{
Allison L. Naleway, PhD, Center for Health Research, Kaiser Permanente Northwest, Portland, Oregon
}

\begin{abstract}
The prevalence of asthma and other atopic diseases has recently increased, especially in urban and modernized regions of the world. The majority of published prevalence surveys report that asthma and atopy are less common among children living in rural areas. While many exposures differ in rural and urban areas of the world, several recent studies have suggested that agricultural exposures in early childhood may decrease the risk of developing atopic disease. Livestock exposure, in particular, seems to be important, but additional research is needed to pinpoint the underlying mechanisms behind this apparent protective effect of rural and farm living. Additionally, prospective studies are needed to more closely examine the timing of farm exposures in relation to the onset of asthma and atopy, and to determine if the apparent protective effects of farming persist into adulthood.
\end{abstract}

\section{INTRODUCTION}

The prevalence of asthma and other atopic diseases, such as hay fever and atopic dermatitis, appears to have increased among children worldwide in recent years, but the reasons behind this increase are currently unknown. The increase has been relatively rapid and dramatic, suggesting that changing environmental factors rather than changing genetic factors have contributed to the increase. ${ }^{1,2}$ Although the definition and diagnosis of these conditions are frequently difficult, the increase in prevalence has been consistently reported and appears to be a real increase rather than just a reflection of changing diagnostic trends.

REPRINT REQUESTS:

Allison Naleway, PhD

Center for Health Research

Kaiser Permanente Northwest

3800 N. Interstate Avenue

Portland, OR 97227

Telephone: 503-335-6352

Fax: 503-335-2428

Email: allison.naleway@kpchr.org
KEYWORDS:

Asthma; Atopy; Rural; Agriculture; Children; Prevalence 
The prevalence of atopic conditions is lower in rural and less-developed areas of the world and higher in areas that are rapidly urbanizing or are modernized. ${ }^{2}$ The reasons for these observed prevalence gradients are currently not well understood. Interestingly, atopic conditions have become more prevalent at the same time that childhood infectious diseases have become less prevalent worldwide, and some researchers have speculated that early life exposures to bacteria and viruses may prevent the development of asthma and atopy in children. 1,3,4

Children living in rural or developing areas often have different infectious disease exposures than urban children, but they are also more likely to reside on farms or engage in farm work. Several recent studies from Europe, Canada, and Australia have suggested that agricultural exposures may protect children from developing asthma and atopy. 5-17 However, these findings are not all consistent, and research has not yet identified the underlying mechanisms of this association. Further, this suggested protection in children contrasts with a host of studies from the occupational literature that suggest adult farmers are at increased risk of respiratory disease. ${ }^{8,18,19}$ Respiratory symptoms in adult farmers have been associated with agricultural exposures such as grain dust, soybean dust, endotoxin, and pesticides. $^{20-25}$

This review highlights findings from several recent studies of asthma and atopy among rural and farm children. Many of these studies hypothesize about the apparent protective effect of rural living and farming, yet they still leave critical questions for future research.

\section{ASTHMA AND ATOPY IN RURAL POPULATIONS}

In general, the reported prevalence of asthma and atopic conditions among children is lower in rural areas than in urban areas (table 1). These differences in observed prevalence can be partially explained by urban and rural differences in environmental exposures, such as air pollution and home heating, and allergens, such as pollens, cockroaches, and house dust mites. ${ }^{26-31}$ Other urban-rural lifestyle differences could affect the prevalence of asthma and atopy. Rural children typically have more siblings, ${ }^{11,29,30}$ are exposed to less tobacco smoke at home, ${ }^{27-29,32}$ and are more likely to own pets or be exposed to animals than are urban children. $11,27,29,31,32$ Studies have also looked at urban-rural differences in exercise and diet. ${ }^{33}$ Although many of these exposures are frequently associated with asthma and atopy, several studies have reported that the protective effect of rural living persists after adjusting for these exposures. ${ }^{11,27,33}$

\section{ASTHMA AND ATOPY IN FARMING POPULATIONS}

Many children living in rural areas are exposed to agriculture by residing, working, and playing on farms. Agricultural exposures that may affect respiratory health and atopy include endotoxin, grain dust, soybean dust, pesticides, livestock, and zoonotic pathogens. ${ }^{19,20,22-25}$ Several recent studies from Europe and Canada suggest that farm children are less likely to develop asthma and other atopic conditions than non-farm children (table 2). Ernst and Cormier evaluated 1,199 rural children 12 to 19 years of age in Quebec, Canada. ${ }^{7}$ The odds ratio for being raised on a farm and having a diagnosis of asthma was 0.59 (95\% confidence interval (CI): 0.37-0.95) after adjusting for gender and smoking. Children raised on a farm also had reduced atopic sensitization (odds ratio $(\mathrm{OR})=0.58 ; 95 \% \mathrm{CI}$ : 0.46-0.75). Airway hyperresponsiveness and hay fever were also less common among children with farm exposures. The associations noted in this study were more pronounced for girls than for boys.

Von Ehrenstein et al. conducted a cross-sectional survey of 10,163 school children in southern Germany. ${ }^{10}$ Children of farmers had a lower prevalence of asthma $(\mathrm{OR}=0.65 ; 95 \%$ CI: 0.39-1.09), hay fever (OR=0.52, 95\% CI: 0.28-0.99), and wheeze $(\mathrm{OR}=0.55$; 95\% CI: 0.36-0.86) compared to children not living on farms. In Switzerland, BraunFahrländer and colleagues examined 1,620 children and report an adjusted odds ratio of 0.31 (95\% CI: 0.13-0.73) for the association between atopic sensitization in children and farming as a parental occupation. ${ }^{5}$ No significant associations were noted for hay fever $(\mathrm{OR}=0.89 ; 95 \% \mathrm{CI}$ : 0.49-1.59), eczema (OR=1.15; 95\% CI: 0.74-1.81), or asthma (OR=1.17; 95\% CI: 0.64-2.13).

A number of studies have found that a decreased prevalence of atopy and asthma is associated not just with farm residence but with livestock exposure in particular. In a cross-sectional survey of 2,283 children in Austria, Riedler et al. report a decreased prevalence of asthma, hay fever, and atopic sensitization among children 8 to 11 years of age living on farms. ${ }^{9}$ Regular contact with livestock was associated with a decreased prevalence of atopic sensitization. This association was even noted for children who did not live on a farm but reported regular contact with livestock.

Remes et al. examined 7,981 children 13 to 14 years of age in Finland. ${ }^{16}$ Living on a farm was associated with a decreased prevalence of allergic rhinoconjunctivitis (OR=0.79, 95\% CI: 0.63-0.99), but was not associated with asthma $(\mathrm{OR}=1.01 ; 95 \% \mathrm{CI}: 0.72-1.41)$, wheeze $(\mathrm{OR}=1.09$; 95\% CI: $0.75-1.56)$, or eczema (OR=1.07; 95\% CI: 0.90 1.28). Models were adjusted for gender, age, geographic region, parental atopy, parental education, smoking, and number of siblings. A trend in the prevalence of allergic rhinoconjunctivitis was observed when farm families were stratified by livestock ownership. Children living on farms with livestock had the lowest prevalence $(\mathrm{OR}=0.70)$, followed by children living on farms without livestock $(\mathrm{OR}=0.89)$ and non-farm children $(P$-value for trend $=0.02)$. No such trend was observed for asthma, wheeze, or eczema. 
Table 1. Prevalence of asthma and other atopic conditions among children in rural regions.

\begin{tabular}{|c|c|c|c|c|c|c|c|c|c|c|c|c|c|c|c|}
\hline \multirow[t]{2}{*}{ Study } & \multirow[t]{2}{*}{ Population } & \multicolumn{2}{|c|}{ Sample size } & \multicolumn{2}{|c|}{ Asthma } & \multicolumn{2}{|c|}{ Wheeze } & \multicolumn{2}{|c|}{$\begin{array}{c}\text { Airway } \\
\text { hyperreactivity }\end{array}$} & \multicolumn{2}{|c|}{$\begin{array}{c}\text { Atopic } \\
\text { sensitization* }\end{array}$} & \multicolumn{2}{|c|}{$\begin{array}{c}\text { Hay } \\
\text { fever/allergic } \\
\text { rhinitis }\end{array}$} & \multicolumn{2}{|c|}{$\begin{array}{l}\text { Eczema/ } \\
\text { atopic dermatitis }\end{array}$} \\
\hline & & Rural & Urban & Rural & Urban & Rural & Urban & Rural & Urban & Rural & Urban & Rural & Urban & Rural & Urban \\
\hline $\begin{array}{l}\text { Gergen et al. } \\
1988^{49}\end{array}$ & $\begin{array}{l}\text { United States } \\
3 \text { to } 17 \text { year olds }\end{array}$ & \multicolumn{2}{|c|}{7399} & $5.7 \%$ & $7.1 \%^{\mathrm{a}}$ & & & & & & & & & & \\
\hline $\begin{array}{l}\text { Crockett and } \\
\text { Alpers } 1992^{47}\end{array}$ & $\begin{array}{l}\text { Australia } \\
5 \text { to } 15 \text { year olds }\end{array}$ & 825 & 1261 & & & $24.1 \%$ & $27.6 \%$ & & & & & $21.3 \%$ & $45.9 \%^{\mathrm{a}}$ & $10.0 \%$ & $16.2 \%^{a}$ \\
\hline $\begin{array}{l}\text { AddoYobo et al. } \\
1997^{48}\end{array}$ & $\begin{array}{l}\text { Ghana } \\
9 \text { to } 16 \text { year olds }\end{array}$ & 276 & 819 & & & & & $2.7 \%$ & $3.4 \%$ & $1.5 \%$ & $5.6 \%^{\mathrm{a}}$ & & & & \\
\hline $\begin{array}{l}\text { Yemaneberhan } \\
\text { et al. } 1997^{32}\end{array}$ & $\begin{array}{l}\text { Ethiopia } \\
\text { all ages }\end{array}$ & 3032 & 9844 & $1.3 \%$ & $3.6 \%^{\mathrm{a}}$ & $1.2 \%$ & $3.7 \%^{\mathrm{a}}$ & & & & & & & & \\
\hline $\begin{array}{l}\text { Nilsson et al. } \\
1999^{27}\end{array}$ & $\begin{array}{l}\text { Sweden } \\
13 \text { to } 14 \text { year olds }\end{array}$ & & 378 & $4.5 \%$ & $11 \%$ & & & & & & & $20 \%$ & $23 \%$ & $24 \%$ & $29 \%$ \\
\hline $\begin{array}{l}\text { Barnes et al. } \\
2001^{11}\end{array}$ & $\begin{array}{l}\text { Crete } \\
11 \text { to } 19 \text { year olds }\end{array}$ & 438 & 559 & & & & & & & $9.6 \%$ & $19.6 \%^{a}$ & & & & \\
\hline Bibi et al. $2002^{28}$ & $\begin{array}{l}\text { Israel } \\
9 \text { to } 12 \text { year olds }\end{array}$ & 85 & 363 & $7.1 \%$ & $6.8 \%$ & & & & & $45.5 \%$ & $63.3 \%^{\mathrm{a}}$ & & & & \\
\hline $\begin{array}{l}\text { Perzanowski et } \\
\text { al. } 2002^{50}\end{array}$ & $\begin{array}{l}\text { Kenya } \\
9 \text { to } 13 \text { year olds }\end{array}$ & 136 & 129 & $3.9 \%$ & $11.2 \%^{a}$ & & & & & $4 \%$ & $14 \%^{\mathrm{a}}$ & & & & \\
\hline $\begin{array}{l}\text { Dagoye et al. } \\
2003^{30}\end{array}$ & $\begin{array}{l}\text { Ethiopia } \\
1 \text { to } 4 \text { year olds }\end{array}$ & 2862 & 4293 & & & $2.0 \%$ & $4.4 \%$ & & & & & & & & \\
\hline $\begin{array}{l}\text { Sudhir and } \\
\text { Prasad 2003 }\end{array}$ & $\begin{array}{l}\text { India } \\
7 \text { to } 15 \text { year olds }\end{array}$ & 200 & 200 & $7 \%$ & $12.5 \%$ & $5.5 \%$ & $12.5 \%^{\mathrm{a}}$ & $10.1 \%$ & $13.2 \%$ & & & $15.5 \%$ & $23.5 \%$ & & \\
\hline
\end{tabular}

Table 2. Prevalence of asthma and other atopic conditions in farm children.

\begin{tabular}{|c|c|c|c|c|c|c|c|c|c|c|c|c|c|c|c|}
\hline \multirow[t]{2}{*}{ Study } & \multirow[t]{2}{*}{ Population } & \multicolumn{2}{|c|}{ Sample size } & \multicolumn{2}{|c|}{ Asthma } & \multicolumn{2}{|c|}{ Wheeze } & \multicolumn{2}{|c|}{$\begin{array}{c}\text { Airway } \\
\text { hyperreactivity }\end{array}$} & \multicolumn{2}{|c|}{$\begin{array}{c}\text { Atopic } \\
\text { sensitization }\end{array}$} & \multicolumn{2}{|c|}{$\begin{array}{c}\text { Hay fever/allergic } \\
\text { rhinitis }\end{array}$} & \multicolumn{2}{|c|}{$\begin{array}{c}\text { Eczemal } \\
\text { atopic dermatitis }\end{array}$} \\
\hline & & Farm & Control & Farm & Control & Farm & Control & Farm & Control & Farm & Control & Farm & Control & Farm & Control \\
\hline $\begin{array}{l}\text { Braun- } \\
\text { Fahrländer et al. } \\
1999^{5}\end{array}$ & $\begin{array}{l}\text { Switzerland } \\
6 \text { to } 15 \text { year olds }\end{array}$ & 307 & 1313 & $7.8 \%$ & $9.6 \%$ & $5.2 \%$ & $9.1 \%^{a}$ & & & & & $7.2 \%$ & $13.3 \%^{\mathrm{a}}$ & $15.6 \%$ & $19.6 \%$ \\
\hline $\begin{array}{l}\text { Omland et al. } \\
1999^{6}\end{array}$ & $\begin{array}{l}\text { Denmark } \\
\text { young adults }\end{array}$ & 1901 & 407 & $8.0 \%$ & $8.4 \%$ & & & $1.9 \%$ & $3.2 \%$ & & & & & & \\
\hline $\begin{array}{l}\text { Ernst and } \\
\text { Cormier } 2000^{7}\end{array}$ & $\begin{array}{l}\text { Canada } \\
12 \text { to } 19 \text { year olds }\end{array}$ & 1034 & 5981 & $5.8 \%$ & $8.3 \%^{a}$ & $20.9 \%$ & $25.8 \%^{\mathrm{a}}$ & $12.9 \%$ & $17.4 \%^{\mathrm{a}}$ & $40.8 \%$ & $53.4 \%^{\mathrm{a}}$ & $30.2 \%$ & $35.0 \%^{\mathrm{a}}$ & $11.3 \%$ & $12.1 \%$ \\
\hline $\begin{array}{l}\text { Masley et al. } \\
2000^{8}\end{array}$ & $\begin{array}{l}\text { Canada } \\
0 \text { to } 17 \text { year olds }\end{array}$ & 316 & 74 & $10.1 \%$ & $10.8 \%$ & & & & & & & & & & \\
\hline $\begin{array}{l}\text { Riedler et al. } \\
2000^{\circ}\end{array}$ & $\begin{array}{l}\text { Austria } \\
8 \text { to } 11 \text { year olds }\end{array}$ & 282 & 1710 & $1.1 \%$ & $3.9 \%^{\mathrm{a}}$ & $4.7 \%$ & $7.5 \%$ & & & $18.8 \%$ & $32.7 \%^{a}$ & $3.1 \%$ & $10.3 \%^{\mathrm{a}}$ & $11.4 \%$ & $10.9 \%$ \\
\hline $\begin{array}{l}\text { Von Ehrenstein } \\
\text { et al. } 2000^{10}\end{array}$ & $\begin{array}{l}\text { Germany } \\
5 \text { to } 7 \text { year olds }\end{array}$ & 1181 & 8466 & $3.4 \%$ & $6.4 \%^{\mathrm{a}}$ & $5.6 \%$ & $8.1 \%^{\mathrm{a}}$ & & & & & $1.8 \%$ & $4.9 \%^{\mathrm{a}}$ & $13.8 \%$ & $15.5 \%$ \\
\hline \multirow[t]{2}{*}{$\begin{array}{l}\text { Downs et al. } \\
2001^{12}\end{array}$} & $\begin{array}{l}\text { Australia } \\
7 \text { to } 12 \text { year olds }\end{array}$ & $\begin{array}{l}142 \\
\text { crop }\end{array}$ & 341 & $43.4 \%$ & $40.6 \%$ & $40.6 \%$ & $41.5 \%$ & & & $46.0 \%$ & $41.0 \%$ & $36.2 \%$ & $29.7 \%$ & & \\
\hline & & $\begin{array}{l}157 \\
\text { mixed }\end{array}$ & 860 & $30.1 \%$ & $40.0 \%^{a}$ & $33.6 \%$ & $43.8 \%^{a}$ & & & $29.7 \%$ & $49.0 \%^{\mathrm{a}}$ & $27.2 \%$ & $36.7 \%^{a}$ & & \\
\hline $\begin{array}{l}\text { Klintberg et al. } \\
2001^{13}\end{array}$ & $\begin{array}{l}\text { Sweden } \\
7 \text { to } 8 \text { year olds }\end{array}$ & 136 & 571 & $2.2 \%$ & $8.6 \%^{a}$ & $8.1 \%$ & $13.0 \%$ & & & $30.7 \%$ & $32.7 \%$ & $3.8 \%$ & $9.7 \%^{\mathrm{a}}$ & $28.7 \%$ & $33.0 \%$ \\
\hline $\begin{array}{l}\text { Riedler et al. } \\
2001^{14}\end{array}$ & $\begin{array}{l}\text { W. Europe } \\
6 \text { to } 13 \text { year olds }\end{array}$ & $593^{b}$ & 170 & $5.4 \%$ & $11.8 \%^{\mathrm{a}}$ & $5.6 \%$ & $15 \%^{\mathrm{a}}$ & & & & & $7.6 \%$ & $20.0 \%^{\mathrm{a}}$ & & \\
\hline $\begin{array}{l}\text { Horak et al. } \\
2002^{15}\end{array}$ & $\begin{array}{l}\text { Austria } \\
7 \text { to } 8 \text { year olds }\end{array}$ & 107 & 603 & & & & & & & $8.4 \%$ & $25.5 \%^{\mathrm{a}}$ & & & & \\
\hline $\begin{array}{l}\text { Remes et al. } \\
2002^{16}\end{array}$ & $\begin{array}{l}\text { Finland } \\
13 \text { to } 14 \text { year olds }\end{array}$ & 924 & 6998 & $5.0 \%$ & $5.6 \%$ & $4.2 \%$ & $4.3 \%$ & & & & & $22.8 \%$ & $26.9 \%^{\mathrm{a}}$ & $23.5 \%$ & $24.3 \%$ \\
\hline \multirow[t]{2}{*}{$\begin{array}{l}\text { Wickens et al. } \\
2002^{34}\end{array}$} & $\begin{array}{l}\text { New Zealand } \\
7 \text { to } 10 \text { year olds }\end{array}$ & $94^{\star \star}$ & 199 & $34 \%$ & $33 \%$ & $20 \%$ & $23 \%$ & & & $32 \%$ & $32 \%$ & $31 \%$ & $33 \%$ & $38 \%$ & $36 \%$ \\
\hline & & $95^{\circ}$ & 198 & $39 \%$ & $31 \%$ & $25 \%$ & $21 \%$ & & & $37 \%$ & $30 \%$ & $39 \%$ & $29 \%$ & $41 \%$ & $34 \%$ \\
\hline $\begin{array}{l}\text { Remes et al. } \\
2003^{17}\end{array}$ & $\begin{array}{l}\text { Finland } \\
6 \text { to } 13 \text { year olds }\end{array}$ & 102 & 136 & & & & & & & $27.9 \%$ & $39.5 \%{ }^{\mathrm{a}}$ & & & & \\
\hline
\end{tabular}


Barnes et al. noted a reduced prevalence of atopic sensitization among children in Crete who had early life contact with livestock (OR=0.67; 95\% CI: 0.46-0.99). ${ }^{11}$ This effect was even observed among urban children who did not live on a farm but reported regular contact with livestock. A similar association was reported for the consumption of unpasteurized milk and decreased prevalence of atopy $(\mathrm{OR}=0.65 ; 95 \%$ CI: $0.41-1.00)$. Riedler et al. also noted a protective effect of livestock exposure and consumption of unpasteurized milk in their cross-sectional survey of school children in Austria, Germany, and Switzerland. ${ }^{14}$ Exposure to stables and farm milk in the first year of life was associated with decreased prevalence of asthma $(\mathrm{OR}=0.14 ; 95 \% \mathrm{CI}$ : $0.04-0.48)$, hay fever ( $\mathrm{OR}=0.20 ; 95 \%$ CI: $0.08-0.50)$, and atopic sensitization ( $\mathrm{OR}=0.32$; $95 \% \mathrm{CI}$ : $0.17-0.62)$.

Many of these studies also suggest that the frequency of exposure to a farm environment and/or to livestock is related to decreasing prevalence of atopy or asthma. In the Von Ehrenstein et al. study, children of full-time farmers had lower risk of atopic disease than children of part-time farmers, and increasing exposure to livestock was associated with decreasing prevalence of atopic disease $(\mathrm{OR}=0.41$; 95\% CI: 0.23-0.74). ${ }^{10}$ In the study conducted by BraunFahrländer et al., children of full-time farmers had lower serum IgE levels than children of part-time farmers suggesting a dose-response effect between farm exposures and atopic sensitization. 5

In a cross-sectional study of children 6 to 13 years of age in Finland, Remes et al. report a decreased prevalence of atopy among farmers' children ( $\mathrm{OR}=0.56 ; 95 \% \mathrm{CI}: 0.40-0.78) .{ }^{17}$ Exposure to livestock was inversely associated with atopy in a dose-dependent manner (OR=0.46; 95\% CI: $0.22-0.97$ for daily contact with livestock compared to no contact with livestock). Pet ownership was also associated with a decreased risk of atopy $(\mathrm{OR}=0.60 ; 95 \% \mathrm{CI}: 0.42-0.85)$.

Two recent studies conducted in farming populations outside of Europe seem to suggest that farm residence without livestock exposure may not affect prevalence rates. Downs and colleagues investigated asthma and atopy among children 7 to 12 years of age from two farming regions in Australia. ${ }^{12}$ No protective effect of farming was observed among children living in a primarily crop farming region. However, the prevalence of asthma and atopy was reduced among farm children living in a region with both livestock and crop farming compared to their non-farm peers from the same region.

In a cross-sectional survey of 293 children from a large-scale livestock and crop farming region in New Zealand, current farm residence was generally associated with increased prevalence of asthma and atopy. ${ }^{34}$ Farm residence during the first year of life also did not appear to protect against asthma and atopy among children 7 to 10 years of age. Early life contact with pigs, and consumption of unpasteurized dairy products, did appear to marginally decrease the prevalence of atopic conditions among both the farm and non-farm children studied.

\section{LIVESTOCK EXPOSURE AND THE "HYGIENE HYPOTHESIS"}

If livestock exposure is indeed associated with a decreased prevalence of asthma and atopy, then additional research is needed to explore the underlying mechanisms of this association. Contact with livestock may increase allergen, dust, and microbial exposures. $5,12,14,16,19,35$ Researchers have proposed a hypothesis that may help explain how microbial exposures relate to the development of asthma and atopy.

The basic premise of the "hygiene hypothesis" is that early life exposures to microbes influence the development of the immune system in a manner that reduces a child's likelihood of developing asthma and atopy. ${ }^{3}$ Specifically, microbial exposures may influence the balance of type 1 (Th1) and type 2 (Th2) helper T cells by promoting Th1 responses and down-regulating Th2 responses. Th1 cells are associated with responses to infection and the production of interferon- $\gamma$. Th2 derived cytokines induce the production of $\operatorname{IgE}$ and the maturation of mast cells, basophils, and eosinophils. Th2 cells are therefore generally associated with "atopic" immune responses.

Children exposed to livestock may be exposed to more bacteria and viruses than are children without livestock exposure. $5,9,12-14,16,35$ In particular, contact with livestock may increase a child's exposure to endotoxin, a component of the outer membrane of gram negative bacteria and a strong promoter of interleukin- 12 and the maturation of naïve T cells into Th1 cells. 5,14,34,36-38 Early childhood exposure to endotoxin may protect against asthma and atopy by promoting Th1 cells and inhibiting Th2 cells. Additionally, several researchers have suggested that children exposed to high levels of endotoxin may develop an immune tolerance to it. 5,13,14,39 Paradoxically, high levels of endotoxin exposure have been shown to exacerbate respiratory symptoms in adult farmers. ${ }^{22,40,41}$ Therefore, the timing and dose of endotoxin exposure seem critical to its association with asthma and atopy.

Clearly, further study is needed to clarify the exact nature of the association between livestock exposure and atopic conditions. In addition to increased endotoxin exposure, children with livestock contact may also be exposed to zoonotic pathogens, dander, feed additives, and dust. 5,12,42 Missing from all these studies of childhood exposures is a comprehensive longitudinal study that follows children exposed to both livestock and crop farming into their adult years. This type of study is particularly necessary, because studies have reported an increased risk of respiratory disease in adult farmers compared to non-farmers. ${ }^{8,18,19}$ It is currently not clear if the apparent protective effect of farm exposures in childhood persists into adulthood. 


\section{ADULT STUDIES}

Three studies have retrospectively examined the association between early life farm exposure and adult asthma and atopy (table 3). Kilpeläinen et al. investigated the relationship between early childhood farm residence and asthma and atopy in 10,667 Finnish university students. ${ }^{35}$ Farm residence in childhood was associated with a decreased prevalence of allergic rhinitis after adjusting for gender, day care attendance, tobacco smoke exposure, parental history of atopy, and number of older siblings ( $\mathrm{OR}=0.63 ; 95 \% \mathrm{CI}$ : $0.50-0.79)$. Early childhood farm residence was not significantly associated with asthma $(\mathrm{OR}=0.70 ; 95 \% \mathrm{CI}$ : 0.46-1.06). Skin prick testing and methacholine challenge testing was performed in a subsample of these young adults. ${ }^{43}$ No difference in airway hyperreactivity was noted, but students who lived on a farm during childhood were more likely to be sensitized to house dust mite $(\mathrm{OR}=5.43$; 95\% CI: 1.60-18.46). Sensitivity to pollens and cats were less common among adults who grew up on farms.

Leynaert et al. surveyed 6,251 adults participating in the European Community Respiratory Health Survey. ${ }^{44}$ Living on a farm in childhood was not associated with asthma $(\mathrm{OR}=0.82 ; 95 \% \mathrm{CI}: 0.53-1.27)$ or wheeze $(\mathrm{OR}=1.09 ; 95 \%$ CI: $0.82-1.46)$ but was significantly associated with a decreased risk of atopic sensitization $(\mathrm{OR}=0.68 ; 95 \% \mathrm{CI}$ : $0.55-0.86$ ). Adults who lived on farms during childhood were less likely to be sensitized to house dust mite and cat than were adults who did not live on a farm.

Atopic sensitization was less common among Danish college students who were raised on farms compared to controls (OR $=0.55$; 95\% CI: 0.40-0.76). ${ }^{45}$ Bronchial hyperreactivity $(\mathrm{OR}=0.61 ; 95 \% \mathrm{CI}: 0.39-0.95)$, asthma $(\mathrm{OR}=0.79 ; 95 \% \mathrm{CI}: 0.49-1.27)$, and rhinoconjunctivitis (OR $=0.70$; 95\% CI: $0.49-0.99)$ were also less common among students raised on a farm, but the association with asthma did not reach statistical significance. The authors also examined students who were working in agriculture at the time of the survey. Atopic sensitization was less common among these students, but no differences in the prevalence of bronchial hyperreactivity, asthma, or rhinoconjunctivitis compared to controls were observed.

\section{DISCUSSION}

The findings from recent studies of European, Canadian, and Australian farm children suggest that farm exposures may confer some protection against asthma and atopy in childhood, but several studies did not observe this relationship. The protective effect appears to be stronger for the development of atopic conditions than for the development of asthma, which is consistent with studies from the adult literature. ${ }^{35,43-45}$ The timing of exposures also appears to be important. Early life exposures tend to confer protection, while later life exposures either do not provide any protection or may exacerbate current symptoms. $., 34,45$

Although, farm children in these studies frequently differed from non-farm children in regards to various exposures such as tobacco smoke, family size, and home heating, the associations between farming and atopic disease often persisted after adjusting for these exposures. $5,7,9,10,12,13,16,17$ Contact with animals was consistently associated with a reduced risk of atopic disease.

Several studies reported that farm children were more likely to own pets than non-farm children, $5,7,13,17,34,43$ and some found a protective effect of pet ownership. ${ }^{13,34,43}$ Although conventional medical advice has been to remove pets from the home to avoid asthma and atopy, it appears that some exposure to pets may actually help protect against these conditions. However, the timing of these exposures seems critical. Early life exposures may be protective, while later life exposures may actually worsen symptoms among children who already have asthma or other atopic conditions. ${ }^{34,46}$

Table 3. Prevalence of asthma and other atopic conditions in adults with early childhood farm exposures.

\begin{tabular}{|c|c|c|c|c|c|c|c|c|c|c|c|c|c|}
\hline \multirow[t]{2}{*}{ Study } & \multirow[t]{2}{*}{ Population } & \multicolumn{2}{|c|}{ Sample size } & \multicolumn{2}{|c|}{ Asthma } & \multicolumn{2}{|c|}{ Wheeze } & \multicolumn{2}{|c|}{$\begin{array}{c}\text { Airway } \\
\text { hyperreactivity }\end{array}$} & \multicolumn{2}{|c|}{$\begin{array}{c}\text { Atopic } \\
\text { sensitization* }\end{array}$} & \multicolumn{2}{|c|}{$\begin{array}{l}\text { Hay fever/allergic } \\
\text { rhinitis }\end{array}$} \\
\hline & & Farm & Control & Farm & Control & Farm & Control & Farm & Control & Farm & Control & Farm & Control \\
\hline $\begin{array}{l}\text { Kilpeläinen et al. } \\
2000^{36}\end{array}$ & Finland & 1095 & 1243 & $3.7 \%$ & $5.3 \%$ & & & & & & & $13.9 \%$ & $20.8 \%{ }^{a}$ \\
\hline $\begin{array}{l}\text { Leynaert et al. } \\
2001^{45}\end{array}$ & Europe & 548 & 5703 & $4.4 \%$ & $4.9 \%$ & $25.0 \%$ & $23.2 \%$ & & & $27.0 \%$ & $35.4 \%^{\mathrm{a}}$ & & \\
\hline \multirow{2}{*}{$\begin{array}{l}\text { Portengen et al. } \\
2002^{46}\end{array}$} & Denmark & $505^{* *}$ & 402 & $5 \%$ & $8 \%$ & $5 \%$ & $12 \%{ }^{a}$ & $6 \%$ & $8 \%$ & $13 \%$ & $27 \%^{a}$ & & \\
\hline & & $494^{\circ}$ & 402 & $9 \%$ & $8 \%$ & $11 \%$ & $12 \%{ }^{\mathrm{a}}$ & $11 \%$ & $8 \%$ & $23 \%$ & $27 \%^{a}$ & & \\
\hline
\end{tabular}

\footnotetext{
* assessed with skin prick testing or serum lgE.

a statistically significant prevalence difference: farmers vs. controls.

** farm residence in early childhood.

${ }^{c}$ current occupational farm exposures.
} 
Several studies have reported a protective effect of early life livestock exposure. ${ }^{9-11,13,14,16,17}$ Children exposed to livestock may be exposed to animal danders, bacteria and viruses, pesticides, feed additives, and dust, $5,9,16,36$ but few studies have examined these more specific exposures in detail. Children exposed to livestock may also be exposed to higher levels of endotoxin as discussed above, and this may confer protection against asthma and atopy. ${ }^{14,34,36}$ Endotoxin exposure, however, may only be a surrogate marker of microbial exposures in the farming environment, and more detailed investigations into specific exposures are needed. 16,38 Data from adult studies suggest that exposures to different types of livestock (cattle, hogs, poultry, etc.) may have different effects on asthma and atopy.6,19,23,25 Generally, poultry and hog farming are associated with increased risk of respiratory symptoms. ${ }^{23,25}$ Most of the livestock exposures in the European studies involved cattle. 13,14,21

\section{Limitations of current studies}

Studies of asthma and atopy in rural and farming populations have primarily been cross-sectional surveys. The prevalence rates from these studies are difficult to compare because varying methods were used to define asthma and atopy. These studies primarily rely on self-reported questionnaire responses about wheeze, allergy symptoms, and diagnosed asthma. Even the more "clinical" measures of atopic sensitization (skin prick testing and serum $\operatorname{IgE}$ ) and bronchial hyperreactivity (methacholine challenge testing) are difficult to compare across studies because of varying methodologies.

It is also difficult to establish the timing of exposure and disease using cross-sectional studies. Several authors have suggested that the decreased prevalence of asthma and atopy observed in some studies may reflect a "healthy farmer effect". $5,12,23,44$ Over time, persons with asthma or atopy symptoms may self-select out of farming into other occupations with less respiratory exposures. Thus, when a cross-sectional survey is performed, asthma and atopy appear less common in the farming population because only the "healthy farmers" have remained in agriculture.

Several studies of farm children have attempted to adjust for this "healthy farmer effect" by collecting information about parental history of asthma and atopy. 5,10,13,16 Parental history of atopic conditions was more common among nonfarm children in some studies, $, 10,16,17,44$ while in others it was not. ${ }^{12,13}$ Importantly, the protective effect of farming remained in many of these studies after adjusting for parental history in multivariable models. $., 10,13,14,16,17,44$

The majority of studies of asthma and atopy in farm children have been conducted in Europe. Most of the farms in Europe are small-scale, family-owned operations, and $85 \%$ to $90 \%$ of farms in these studies reported livestock ownership. 9,10,14,42 Farming practices differ around the world, thus, it is difficult to make inferences about the relationships between farming and atopic diseases without considering other types of farming. The Canadian study conducted by Ernst and Cormier involved large-scale farming operations in Quebec and reported a protective effect $^{7}$; however, the two published Australian studies investigated much larger crop and livestock farming operations and did not consistently report a protective effect. ${ }^{12,34}$

\section{Future directions}

Current studies suggest that rural living and early childhood farm exposures may confer some protection against the development of asthma and atopy, but it is difficult to draw any firm conclusions about causality given the limitations described above. Prospective studies are needed to better examine the timing of farm exposures in relation to the onset of asthma and atopy. Standard definitions of asthma and atopy are needed to facilitate comparisons of data across studies. Studies need to be replicated in various populations with differing agricultural exposures, and specific farm exposures (endotoxin, grain dust, microbes, pesticides, etc.) need to be rigorously evaluated.

\section{ACKNOWLEDGMENTS}

The author thanks Jen Coury and Debra Burch for their assistance with manuscript preparation.

\section{REFERENCES}

1. Woolcock AJ, Peat JK. Evidence for the increase in asthma worldwide. Ciba Foundation Symposium 1997;206:122139.

2. International Study of Asthma and Allergies in Childhood Steering Committee. Worldwide variation in prevalence of symptoms of asthma, allergic rhinoconjunctivitis, and atopic eczema: ISAAC. Lancet 1998;351:1225-1232.

3. Strachan DP. Hay fever, hygiene, and household size. BMJ 1989;299:1259-1260.

4. von Mutius E, Pearce N, Beasley R, Cheng S, von Ehrenstein $\mathrm{O}$, Bjorksten $\mathrm{B}$ et al. International patterns of tuberculosis and the prevalence of symptoms of asthma, rhinitis, and eczema. Thorax 2000;55:449-453.

5. Braun-Fahrländer C, Gassner M, Grize L, Neu U, Sennhauser $\mathrm{FH}$, Varonier HS et al. Prevalence of hay fever and allergic sensitization in farmer's children and their peers living in the same rural community. SCARPOL team. Swiss Study on Childhood Allergy and Respiratory Symptoms with Respect to Air Pollution. Clin Exp Allergy 1999;29:28-34.

6. Omland Ø, Sigsgaard T, Hjort C, Pedersen OF, Miller MR. Lung status in young Danish rurals: the effect of farming exposure on asthma-like symptoms and lung function. Eur Respir J 1999;13:31-37.

7. Ernst P, Cormier Y. Relative scarcity of asthma and atopy among rural adolescents raised on a farm. Am J Respir Crit Care Med 2000;161:1563-1566.

8. Masley ML, Semchuk KM, Senthilselvan A, McDuffie HH, Hanke P, Dosman JA et al. Health and environment of rural families: results of a Community Canvass survey in the Prairie Ecosystem Study (PECOS). J Agric Saf Health 2000;6:103-115.

9. Riedler J, Eder W, Oberfeld G, Schreuer M. Austrian children living on a farm have less hay fever, asthma and allergic sensitization. Clin Exp Allergy 2000;30:194-200. 
10. Von Ehrenstein OS, von Mutius E, Illi S, Baumann L, Böhm O, von Kries R. Reduced risk of hay fever and asthma among children of farmers. Clin Exp Allergy 2000;30:187-193.

11. Barnes M, Cullinan P, Athanasaki P, MacNeill S, Hole AM, Harris J et al. Crete: does farming explain urban and rural differences in atopy? Clin Exp Allergy 2001;31:18221828.

12. Downs SH, Marks GB, Mitakakis TZ, Lëuppi JD, Car NG, Peat JK. Having lived on a farm and protection against allergic diseases in Australia. Clin Exp Allergy 2001;31:570-575.

13. Klintberg B, Berglund N, Lilja G, Wickman M, van HageHamsten M. Fewer allergic respiratory disorders among farmers' children in a closed birth cohort from Sweden. Eur Respir J 2001;17:1151-1157.

14. Riedler J, Braun-Fahrländer C, Eder W, Schreuer M, Waser M, Maisch S et al. Exposure to farming in early life and development of asthma and allergy: a cross-sectional survey. Lancet 2001;358:1129-1133.

15. Horak F, Studnicka M, Gartner C, Veiter A, Tauber E, Urbanek R et al. Parental farming protects children against atopy: longitudinal evidence involving skin prick tests. Clin Exp Allergy 2002;32:1155-159.

16. Remes ST, Pekkanen J, Soininen L, Kajosaari M, Husman T, Koivikko A. Does heredity modify the association between farming and allergy in children? Acta Paediatr 2002;91:1163-1169.

17. Remes ST, Iivanainen K, Koskela H, Pekkanen J. Which factors explain the lower prevalence of atopy amongst famers' children? Clin Exp Allergy 2003;33:427-434.

18. Bener A, Lestringant GG, Beshwari MM, Pasha MA. Respiratory symptoms, skin disorders and serum $\operatorname{IgE}$ levels in farm workers. Allerg Immunol (Paris) 1999;31:52-56.

19. Vogelzang PF, van der Gulden JW, Tielen MJ, Folgering H, van Schayck CP. Health-based selection for asthma, but not for chronic bronchitis, in pig farmers: an evidencebased hypothesis. Eur Respir J 1999;13:187-189.

20. Senthilselvan A, McDuffie HH, Dosman JA. Association of asthma with use of pesticides: results of a cross-sectional survey of farmers. Am Rev Respir Dis 1992;146:884-887.

21. Prior C, Falk M, Frank A. Early sensitization to farmingrelated antigens among young farmers: analysis of risk factors. Int Arch Allergy Immunol 1996;111:182-187.

22. American Thoracic Society. Respiratory health hazards in agriculture. Am J Respir Crit Care Med 1998;158:S1-S76.

23. Kimbell-Dunn M, Bradshaw L, Slater T, ErkinjunttiPekkanen R, Fishwick D, Pearce N. Asthma and allergy in New Zealand farmers. Am J Ind Med 1999;35:51-57.

24. Spiewak R, Góra A, Horoch A, Dutkiewicz J. Atopy, allergic diseases and work-related symptoms among students of agricultural schools: first results of the Lublin study. Ann Agric Environ Med 2001;8:261-267.

25. Hoppin JA, Umbach DM, London SJ, Alavanja MC, Sandler DP. Animal production and wheeze in the Agricultural Health Study: interactions with atopy, asthma, and smoking. Occup Environ Med 2003;60:e3.

26. Noorhassim I, Rampal KG, Hashim JH. The relationship between prevalence of asthma and environmental factors in rural households. Med J Malaysia 1995;50:263-267.

27. Nilsson L, Castor O, Löfman O, Magnusson A, Kjellman NI. Allergic disease in teenagers in relation to urban or rural residence at various stages of childhood. Allergy 1999;54:716-721.
28. Bibi H, Shoseyov D, Feigenbaum D, Nir P, Shiachi R, Scharff $\mathrm{S}$ et al. Comparison of positive allergy skin tests among asthmatic children from rural and urban areas living within small geographic area. Ann Allergy Asthma Immunol 2002;88:416-420.

29. Kauffmann F, Oryszczyn MP, Maccario J. The protective role of country living on skin prick tests, immunoglobulin $\mathrm{E}$ and asthma in adults from the Epidemiological Study on the Genetics and Environment of Asthma, Bronchial Hyper-responsiveness and Atopy. Clin Exp Allergy 2002;32:379-386.

30. Dagoye D, Bekele Z, Woldemichael K, Nida H, Yimam M, Hall A et al. Wheezing, allergy, and parasite infection in children in urban and rural Ethiopia. Am J Respir Crit Care Med 2003;167:1369-1373.

31. Sudhir P, Prasad CE. Prevalence of exercise-induced bronchospasm in schoolchildren: an urban-rural comparison. J Trop Pediatr 2003;49:104-108.

32. Yemaneberhan H, Bekele Z, Venn A, Lewis S, Parry E, Britton J. Prevalence of wheeze and asthma and relation to atopy in urban and rural Ethiopia. Lancet 1997;350:8590 .

33. Hijazi N, Abalkhail B, Seaton A. Diet and childhood asthma in a society in transition: a study in urban and rural Saudi Arabia. Thorax 2000;55:775-779.

34. Wickens K, Lane JM, Fitzharris P, Siebers R, Riley G, Douwes $\mathrm{J}$ et al. Farm residence and exposures and the risk of allergic diseases in New Zealand children. Allergy 2002;57:1171-1179.

35. Kilpeläinen M, Terho EO, Helenius H, Koskenvuo M. Farm environment in childhood prevents the development of allergies. Clin Exp Allergy 2000;30:201-208.

36. von Mutius E, Braun-Fahrländer C, Schierl R, Riedler J, Ehlermann S, Maisch S et al. Exposure to endotoxin or other bacterial components might protect against the development of atopy. Clin Exp Allergy 2000;30:12301234.

37. Braun-Fahrländer C, Lauener R. Farming and protective agents against asthma and allergy. Clin Exp Allergy 2003;33:409-411.

38. Braun-Fahrländer C. Environmental exposure to endotoxin and other microbial products and the decreased risk of childhood atopy: evaluating developments since April 2002. Curr Opin Allergy Clin Immunol 2003;3:325-329.

39. Platts-Mills T, Vaughan J, Squillace SP, Woodfolk J, Sporik R. Sensitisation, asthma, and a modified Th2 response in children exposed to cat allergen: a population-based cross-sectional study. Lancet 2001;357:752-756.

40. Iversen M, Kirychuk S, Drost H, Jacobsen L. Human health effects of dust exposure in animal confinement buildings. J Agric Saf Health 2000;6:283-288.

41. Radon K, Garz S, Schottky A, Koops F, Hartung J, Szadkowski D et al. Lung function and work-related exposure in pig farmers with respiratory symptoms. J Occup Environ Med 2000;42:814-820.

42. Braun-Fahrländer $\mathrm{C}$. The role of the farm environment and animal contact for the development of asthma and allergies. Clin Exp Allergy 2001;31:1799-1803.

43. Kilpeläinen M, Terho EO, Helenius H, Koskenvuo M. Childhood farm environment and asthma and sensitization in young adulthood. Allergy 2002;57:1130-1135.

44. Leynaert B, Neukirch C, Jarvis D, Chinn S, Burney P, Neukirch F. Does living on a farm during childhood protect against asthma, allergic rhinitis, and atopy in adulthood? Am J Respir Crit Care Med 2001;164:18291834. 
45. Portengen L, Sigsgaard T, Ømland O, Hjort C, Heederik D, Doekes G. Low prevalence of atopy in young Danish farmers and farming students born and raised on a farm. Clin Exp Allergy 2002;32:247-253.

46. Johnson CC, Alford SH. Do animals on the farm and in the home reduce the risk of pediatric atopy? Curr Opin Allergy Clin Immunol 2002;2:133-139.

47. Crockett AJ, Alpers JH. A profile of respiratory symptoms in urban and rural South Australian school children. J Paediatr Child Health 1992;28:36-42.

48. Addo Yobo EO, Custovic A, Taggart SC, Asafo-Agyei AP, Woodcock A. Exercise induced bronchospasm in Ghana: differences in prevalence between urban and rural schoolchildren. Thorax 1997;52:161-165.

49. Gergen PJ, Mullally DI, Evans R. National survey of prevalence of asthma among children in the United States, 1976 through 1980. Pediatrics 1988;81:1-7.

50. Perzanowski MS, Ng'ang'a LW, Carter MC, Odhiambo J, Ngari P, Vaughan JW et al. Atopy, asthma, and antibodies to Ascaris among rural and urban children in Kenya. J Pediatr 2002;140:582-588. 